\title{
Hanging as a method of suicide: a retrospective study
}

Abd Alkareem Q. Mohammed ${ }^{1}$

\section{ABSTRACT}

Objectives: Hanging is a common cause of death worldwide as well as a method of suicide with a high fatality rate, In this retrospective study, data were obtained from cases of hanging reported to Department of Forensic Medicine at the province of Basrah, Iraq, in order to analyze the characteristics of hanging, to focus on its distribution by gender, age groups, marital status, the place of occurrence of the incident, ligature types used, autopsy findings and manner of death, and to determine the possible causes of hanging fatalities over the period of the study, in addition to various other associated factors with the aim to find out which individuals are more prone to death by hanging and to explore the potential control and preventive measures.

Methodology: Over a period of seven years, from January 2010 to December 2016. data from autopsy reports, together with information from police investigation reports and history obtained from relatives were used in this study.

Results: A total of $\mathbf{1 8 4}$ forensic autopsies were conducted on cases of death due to hanging during the period of the study. The highest proportion of hanging cases was suicidal in nature (86\%). Twenty eight percent of the suicidal hanging victims were in their $3^{\text {rd }}$ decade of life, and the incidence rate of hanging among female and male victims was almost equal, female to male ratio was 1.1:1.

Conclusion: Hanging is a common cause of suicide in our society, especially among young individuals. Prevention of death by hanging is not easy since different types of materials can be used as a ligature.

Keywords: Hanging, suicide, Basrah

$$
\text { دراسة استعادية لحالات الانتحار بواسطة الشنق }
$$

المقدمة: يعتبر الشنق سببا شائعا للموت في العالم وطريقة انتحار بمعدل وفيات عالي وفي هذه الدراسة تم اخذ المعلومات من خلال حالات الوفيات شنقا الواردة الى قسم الطبابة العدلية في محافظة البصرة في العراق لغرض تصنيف الحالات وفقا للجنس والفئات العمرية والحالة الزوجية ومكان الحادث ونوع الرباط المستخدم وطبيعة الحادث لتحديد اسباب الوفيات عن طريق الثنق واكثر الاشخاص عرضة للموت شنقا لغرض اكتشاف طرق الوقاية والسيطرة.

طريقة العمل: خلال سبعة سنوات من كانون الثاني • 1 • ا الى كانون الاول ج 1 • ب تم اخذ المعلومات من التقارير التشريحية وتقارير الثرطة اضافة الى المعلومات التي تم اخذها من اقارب المتوفين.

النتائج: أجريت ع 1 أعملية تشريح لوفيات ناتجة عن الشنق خلال فترة الدراسة وكانت الغالبية العظمى لحالات الشنق هي ذات طبيعة انتحارية

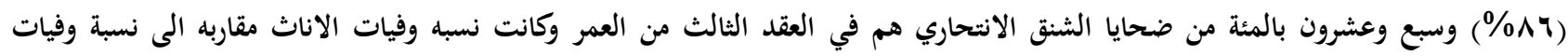

الاستنتاج: يعتبر الشنق سببا شائعا للموت الاختناقي في مجتمعنا وخاصة بين فئة الشباب اذ يمكن استخدام مواد مختلفة واستعمالها كرباط للشنق مما يجعل من الصعب السيطرة عليه. الكلمات المفتاحية: الشنق، الانتحار، البصرة

${ }^{1}$ M.D, Phd, Forensic Medicine, Department of Pathology and Forensic Medicine, College of Medicine, University of Basrah, Iraq 


\section{INTRODUCTION}

$\mathrm{H}$ anging is the suspension of the body by the neck with a ligature, and the pressure of the ligature on the neck is produced by the weight of the body. It has been used as a capital punishment since medieval ages, [1] and it was a suicidal method in primitive and pre-industrial societies. ${ }^{[2]}$ A thin rope around the neck will produce unconsciousness in 15 seconds, and death occurs within few minutes, ${ }^{[3,4]}$ which may occur due to asphyxia, cerebral anoxia, vagal inhibition or injury to the spinal cord. ${ }^{[5,6]}$ Hanging is one of the 10 leading causes of death in the world, with more than million deaths annually, ${ }^{[7]}$ it's one of the most common methods of suicides worldwide and it's particularly favored by men. ${ }^{[8]}$ Homicide in cases of hanging is very rare in adult victims unless intoxicated or made unconscious, but a person maybe murdered and the body suspended to simulate suicide, while accidental hanging deaths usually occur in children and sometimes in adult (autoerotic hanging). ${ }^{[9]}$ In this study, data were collected retrospectively from cases of death due to hanging over a period of seven years in Basrah, Iraq, in order to review the incidence of hanging, identifying the associated factors and to explore the magnitude of the problem with the possible means of intervention.

\section{MATERIAL AND METHODS}

In this retrospective study, data were obtained from cases of hanging reported to the department of Forensic Medicine in Basrah province, Iraq over a period of seven years, from January 2010 to December 2016. Data from autopsy reports along with information from police investigation reports and history obtained from relatives were analysed according to age groups, gender, type of ligature, occupation, place and time of death, place of incident, autopsy findings, manner of death, details of toxicology report and previous psychiatric history. Cases of judicial hanging were not included in this study.

\section{RESULTS}

The present study revealed a total of 184 cases of death due to hanging over a period of seven years at Basrah province. These hanging cases constituted $2 \%$ of the total autopsies performed during that period. Cases of hanging in females were $81(51 \%)$ and $78(49 \%)$ in males, the mean age for both male and female was 22(ranging from 6 to 63). In majority of victims 159(86\%), autopsy findings and investigation reports revealed that the manner of death was suicide, $11(6 \%)$ was identified as accidental hangings, while manner of death in the remaining $14(8 \%)$ cases was classified as undetermined (Fig.1). In suicidal hangings, 44 victims $(27 \%)$ lie within 21-30 age groups (Table-1). 


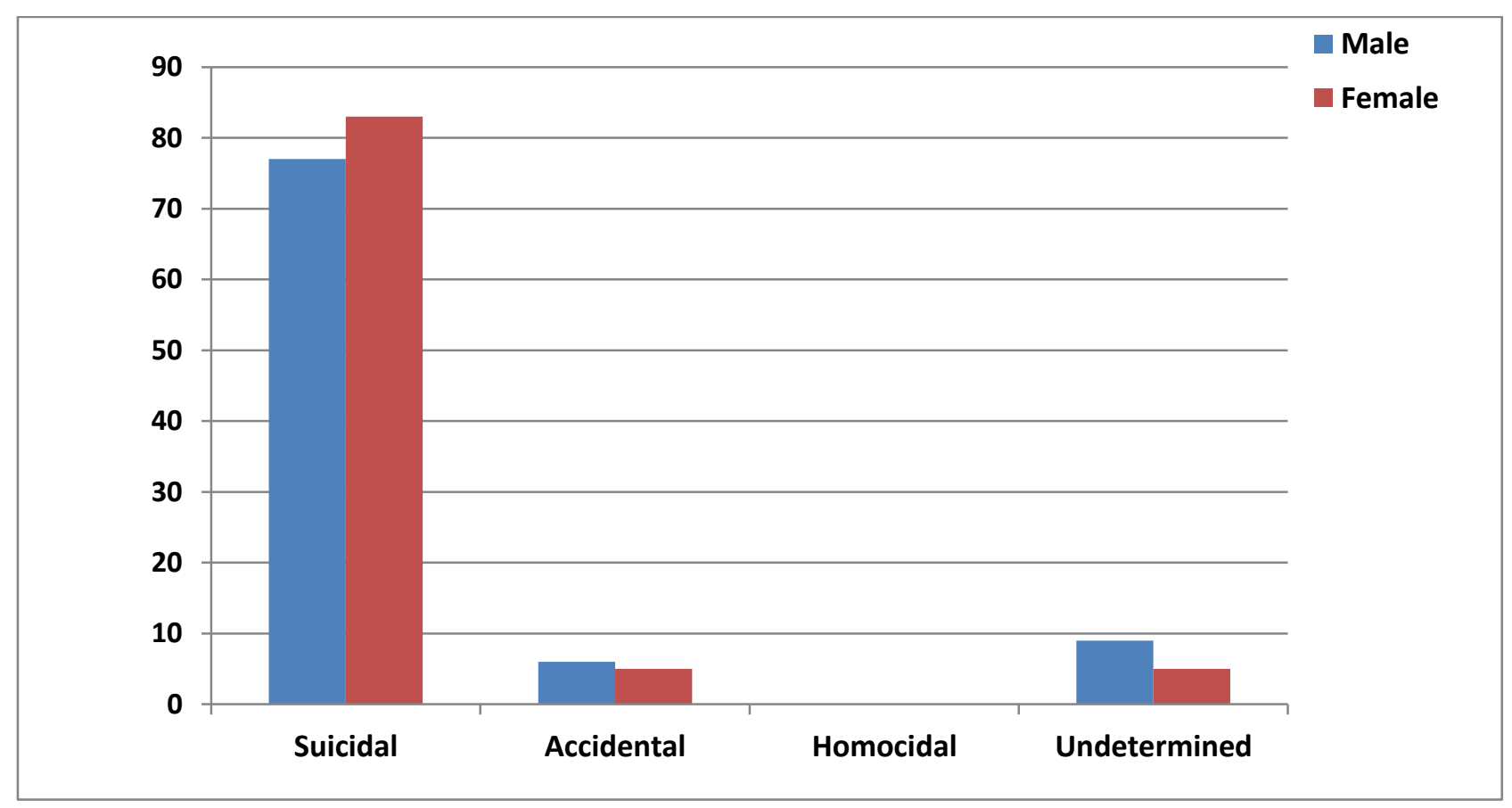

Fig 1. Manner of death

Table 1. Age groups and sex distribution of suicidal hangings.

\begin{tabular}{|c|c|c|c|}
\hline $\begin{array}{c}\text { Age group } \\
\text { Total years } \\
\text { No. }(\%) \\
\end{array}$ & $\begin{array}{c}\text { Males } \\
\text { No. }(\%)\end{array}$ & $\begin{array}{l}\text { Females } \\
\text { No. }(\%)\end{array}$ & $\begin{array}{c}\text { Total } \\
\text { No. }(\%)\end{array}$ \\
\hline$<10$ & $0(0)$ & $0(0)$ & $0(0)$ \\
\hline $10-20$ & $16(10)$ & $18(11)$ & $34(21)$ \\
\hline 21-30 & 21(13) & $23(14)$ & 44 (27) \\
\hline $31-40$ & $15(9)$ & $17(11)$ & $32(20)$ \\
\hline $41-50$ & $12(8)$ & $11(7)$ & $23(15)$ \\
\hline $51-60$ & $8(5)$ & $9(6)$ & 17 (11) \\
\hline$>60$ & $6(4)$ & $3(2)$ & $9(6)$ \\
\hline Total & $78(49)$ & $81(51)$ & $159(100)$ \\
\hline
\end{tabular}

Nearly half of the victims $(48 \%)$ were found fully suspended in a position of complete hanging, and different types of materials was used as a ligature, in about half of the victims (44\%), ligature used was clothes, followed by electric wires 48(26\%), rope in $39(21 \%)$, and other materials $16(9 \%)$, (Table-2). In the vast majority of cases $172(93 \%)$, the place of hanging was their own residency, particularly their own room or bathroom, the remaining occurred in random indoor and outdoor places. Regarding time during the day most of incidents $(80 \%)$ took place between $3 \mathrm{pm}$ and $3 \mathrm{am}$. 
Table 2. Ligature types.

\begin{tabular}{|l|c|c|c||}
\hline $\begin{array}{l}\text { Ligature type } \\
\text { No. (\%) }\end{array}$ & $\begin{array}{c}\text { Males } \\
\text { No. (\%) }\end{array}$ & $\begin{array}{c}\text { Females } \\
\text { No. (\%) }\end{array}$ & $\begin{array}{c}\text { Total } \\
\text { No. (\%) }\end{array}$ \\
\hline Clothes & $33(18)$ & $48(26)$ & $81(44)$ \\
\hline Electric wire & $26(14)$ & $22(12)$ & $48(26)$ \\
\hline Rope & $22(12)$ & $17(9)$ & $39(21)$ \\
\hline Other materials & $9(5)$ & $7(4)$ & $16(26)$ \\
\hline
\end{tabular}

In postmortem examination, all victims showed dryness of skin under ligature mark, while petechial hemorrhages observed in $63 \%$ of the deceased, subconjunctival haemorrhage in $58 \%$, and face congestion was observed in $27 \%$.

Table 3. Autopsy findings.
However neither hyoid bone fracture nor thyroid cartilage fracture or vertebral fracture were noticed. Minor abrasions and contusions on different parts of the body were present in only $9 \%$ (Table-3).

\begin{tabular}{|l|c|c|c|}
\hline \multicolumn{1}{|c|}{ Autopsy Findings } & $\begin{array}{c}\text { Males } \\
\text { No. }(\%)\end{array}$ & $\begin{array}{c}\text { Females } \\
\text { No. }(\%)\end{array}$ & $\begin{array}{c}\text { Total } \\
\text { No. }(\%)\end{array}$ \\
\hline Dryness under Ligature mark & $89(48)$ & $95(52)$ & $184(100)$ \\
\hline Petechial hemorrhages & $60(33)$ & $56(30)$ & $116(63)$ \\
\hline Subconjunctival haemorrhage & $55(30)$ & $51(28)$ & $106(58)$ \\
\hline Face congestion & $24(13)$ & $26(14)$ & $50(27)$ \\
\hline $\begin{array}{l}\text { Abrasions and contusions } \\
\text { (Not caused by ligature) }\end{array}$ & $10(5)$ & $8(4)$ & $18(9)$ \\
\hline $\begin{array}{l}\text { Thyroid cartilage, vertebral } \\
\text { and hyoid bone fracture }\end{array}$ & $0(0)$ & $0(0)$ & $0(0)$ \\
\hline
\end{tabular}

In post-mortem toxicological investigation 9 victims was positively identified for alcohol. No drug or toxic substance was identified in any of the deceased. More than half of victims (56\%) were married and when it comes to causes and factors associated with suicidal hanging, $65 \%$ of the families and relatives denied any previous suicidal intent or certain issues that might be referred to as a cause for their deceased to hang themselves, while previous psychiatric history was identified in $18 \%$, family problems in $13 \%$, and marital conflicts in 5\% (Fig.2). With the growing rate of population, there was an increasing trend of hanging deaths in Basra during the period of the study (Fig.3). 

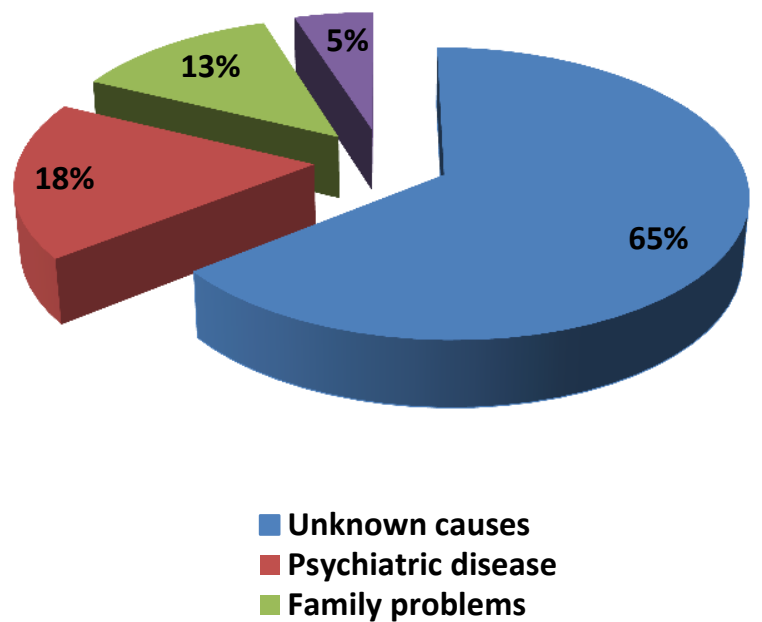

Fig 2. Causes of suicidal hanging

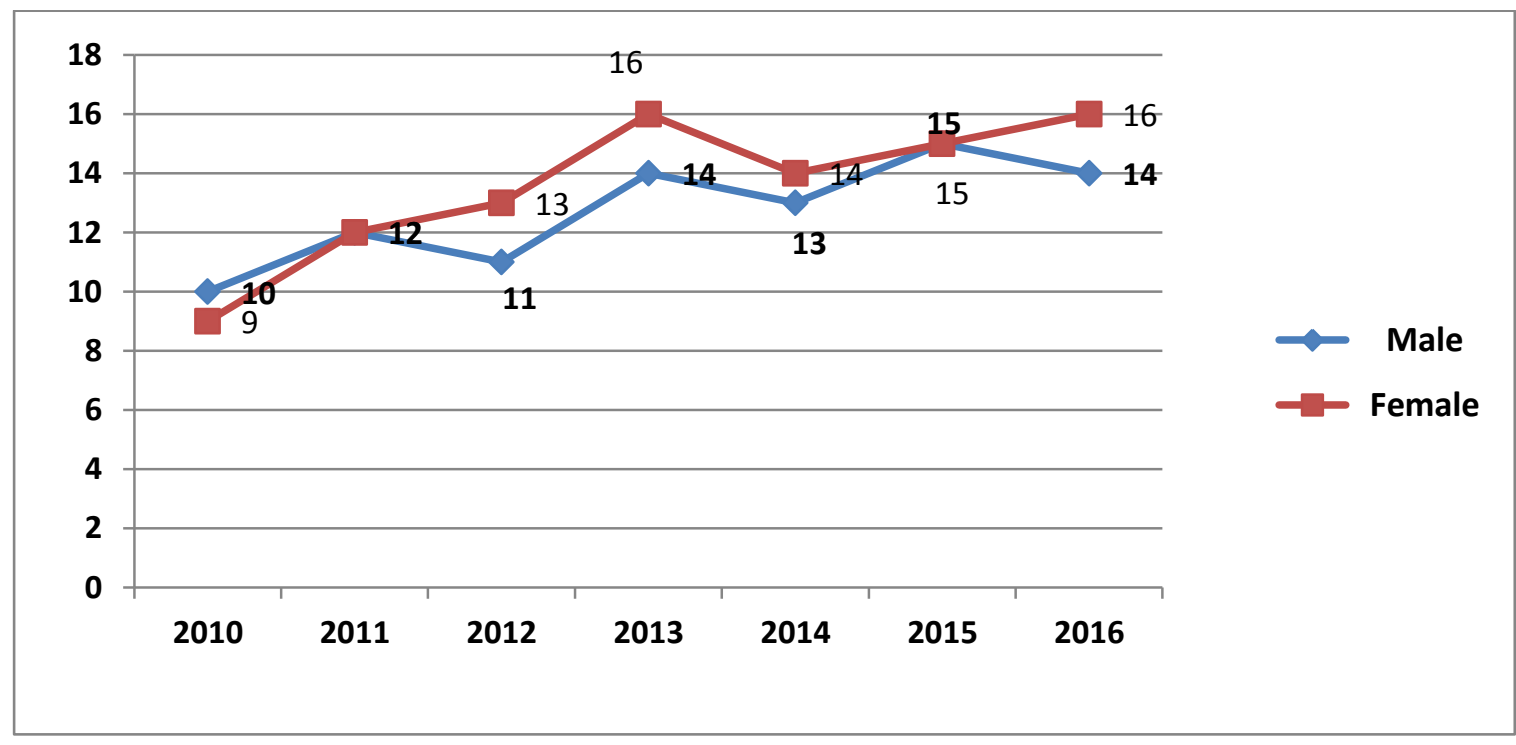

Fig 3. Numbers of hanging cases over the seven years period of the study

\section{DISCUSSION}

Hanging is a frequently used method of suicide in many countries, ${ }^{[10]}$ and it's well known that almost all cases of hanging are suicidal, however there are occasional accidental hangings, and homicides are extremely rare. ${ }^{[11]}$ In Iraq, like many other countries, all cases of death due to hanging should be subjected to medicolegal post-mortem examination. With the growing population of Basrah city, hanging deaths seems to be increased within the last several years in this city from 19 cases in 2010 to 30 in 2016. The rate of suicidal hanging, particularly among young individuals have been increased which is consistent with several other studies in both developing and developed countries. Hanging is a particularly lethal method of suicide with over $70 \%$ fatality rate. [12-14] In mechanical constriction of the neck 
structures, $2 \mathrm{~kg}$ of pressure is enough to block the jugular veins, while $2.3-30.0 \mathrm{~kg}$ is required to occlude the cerebral arterial supply, and about $15 \mathrm{~kg}$ of pressure is required to obstruct the trachea. ${ }^{[15]}$ Although little is known about methods of committing suicide in Iraq, however, along with hanging, individuals may use self-immolation, suicidal firearm and different other methods to commit suicide, and while suicidal hanging mostly seen in males in many countries around the world, ${ }^{[16]}$, our study have shown that suicidal hanging is slightly higher in females (52\%) than males, which might be explained by suicidal firearm fatalities which are often seen in males in Iraq. A recent study in Baghdad, the capital city of Iraq have concluded that with the exclusion of suicidal firearm deaths, hanging was the second commonest method of committing suicide after poison ingestion, and similar to our study, suicidal hanging deaths among females was slightly higher than males, the same study also identified low socioeconomic conditions, psychosocial causes as the most frequent causes for committing suicide. ${ }^{[17]}$ In Iran, a study have resulted that hanging is the commonest method of suicide in Tehran city, the study also revealed that the proportion of women who hanged themselves was slightly higher than that of men when its compared to other methods of suicide. [18] In England, hanging is also the most commonly used suicide method, there are around 2000 hanging suicides per year. ${ }^{[19-21]}$ In contrast, hanging in the United States is considered the second commonest method of committing suicide following suicidal firearm deaths, ${ }^{[22-25]}$ in India suicidal hanging fatalities comes after intoxication. [26] In our society as well as in many other Arab and Middle-Eastern countries, suicidal death considered as a stigma and a shameful act, some families would report hanging and relate it to accidental or unknown circumstances. The rate of suicidal hanging deaths in Iraq was seen to be increased during the period of this study, the opposite was observed in Istanbul, Turkey despite the growing population of this crowded city, ${ }^{[27]}$ similar observation was noticed in the neighboring state of Kuwait where the decreasing trend of suicidal hanging have been linked to the highest standard of living and working as well as the role of the society in condemning suicidal acts. ${ }^{[28]}$ However, since Materials used for hanging are easily accessed and readily available, hanging considered simple to perform and some individuals believe it's a clean, rapid method of suicide which does not damage the body or leave harrowing images to others, ${ }^{[29]}$ socio-cultural acceptability, media portrayals are an important factor in influencing individuals to choose hanging as a method of suicide. ${ }^{\left[{ }^{[0]}\right.}$ In this study some of the deceased relatives gave history of domestic and/or marital conflicts and most of suicidal hangings was seen especially among young age groups which could be related to frustration, lack of job, poverty and other various reasons which motivate individuals to commit suicide. Some studies in India and Bangladesh have shown that marital unhappiness, family problems, poverty and unemployment are common precipitating factors for suicidal hangings. ${ }^{[31-34]}$ Since wide range of ligatures can be used in hanging, it is considered difficult to prevent, ${ }^{[35]}$ prevention of hanging, particularly suicidal hanging is not easy as controlling the factors which promote individuals to commit suicide in general, some studies suggested that suicidal hanging might be controlled through media to reduce the portrayal of fictional suicides by hanging. ${ }^{[36]}$

In conclusions, hanging is a common cause of suicide in our society and the highest proportion of hanging cases in this study was found to be suicidal in nature, and the most involved age group was 21-30 years which is similar to findings found in different other countries. The number of female victims was almost equal to males. The fact that different types of ligatures and hanging points can be used in hanging makes prevention strategies difficult to be applied, and since most suicidal hangings was seen among young age individuals, it imposes a 
burden on our society. More concern should be focused on young individuals to raise the awareness about hanging, further researches might be required in order to bring the focus on this problem and factors which drive individuals to commit suicide.

\section{REFERENCES}

1. Mahmoud Rayes, Monika Mittal, Setti S. Rengachary, Sandeep Mittal (February 2011). "Hangman's fracture: a historical and biomechanical perspective".

2. Comprehensive Textbook of Suicidology Ronald W. Maris, Alan A. Berman, Morton M. Silverman.

3. Knight's forensic pathology, Third Edition, Pekka Saukko, Bernard Knight.

4. Gorden I, Shapiro HA, Berson SD (1998) Forensic Medicine - A guide to principles. 3rd edition, Deaths usually initiated by hypoxic hypoxia or anoxic anoxia, 95-127.

5. Nageshkumar G Rao (2010) Forensic Medicine \& Toxicology. 2nd edition Jaypee Brothers Medical Publishers, 179, 195.

6. Dimaio VI, Dimaio D (2001) Forensic Pathology, 2nd edition, CRC Press, USA, 245257.

7. Mohanty S, Sagu H, Mohanty MK, Patnaik M. Suicide in India: A four year retrospective study. J Forensic Leg Med 2007; 14(2):185-189.

8. Simpson's Forensic Medicine 13th ed. - J. Payne-James, et. al. 2011.

9. Review of Forensic Medicine and Toxicology (Including Clinical \& Pathological Aspects) Third Edition.

10. Department of Social Medicine, University of Bristol, Bristol BS8 2PR, UK.

11. Handbook of Forensic Medicine, Edited by Burkhard Madea.

12. Simounet C, Bourgeois M. Suicides and attempted suicides by hanging. Ann Med Psychol 1992;150:481-85.

13. Aufderheide TP, Aprahamian C, Mateer JR et al. Emergency airway management in hanging victims. Ann Emerg Med 1994; 24:879-884.

14. Luke JL, Reay DT, Eisele JW, Bonnell HJ. Correlation of circumstances with pathological findings in asphyxial deaths by hanging: a prospective study of 61 cases from Seattle, WA. J Forensic Sci 1985; 30: 1140-1147.
15. Iserson KV. Strangulation: a review of ligature, manual, and postural neck compression injuries. Ann Emerg Med 1984;13: 179-185.

16. Lowy A, Burton P, Briggs A (1990) Increasing suicide rates in young adults. BMJ 300: 643 .

17. Mohammad A. Jabor, Suhaila Saleem Kareem "Causes, Attempts and Methods of Suicide in Baghdad: An Autopsy Study. AJPS, 2016, Vol. 16, No.2.

18. The Most Common Method of Suicide in Tehran 2000-2004, Crisis 2008; 29(3): 164-166.

19. Centre for Suicide Research, University of Oxford Department of Psychiatry, Warneford Hospital, Headington, Oxford OX3 7JX, UK.

20. Brock A, Griffiths C. Trends in Suicide by method in England and Wales, 1979-2001. Health Stat Quart 2003; 20: 7-18.

21. Middleton N, Gunnell D. Trends in suicide in England and Wales. Br J Psychiatry 2000; 176: 595.

22. "Suicide in the U.S. Statistics and Prevention". National Institute of Mental Health. Accessed 2 August 2011.

23. Shields LB, Hunsaker DM, Hunsaker JC. Suicide: a ten-year retrospective review of Kentucky medical examiner cases. J Forensic Sci 2005; 50(3): 613e7.

24. Centers for Disease Control and Prevention. (2000). National injury mortality reports, 19871998. Atlanta.

25. Methods of suicide: international suicide patterns derived from the WHO mortality database Vladeta Ajdacic-Gross, Mitchell G Weiss, Mariann Ring, Urs Hepp, Matthias Bopp, Felix Gutzwiller, Wulf Rössler 2008; 86(9): 726-732.

26. Ojima T, Nakamura Y, Detels R. Comparative study about methods of suicide between Japan and the United States. J Epidemiol 2004; 19(9): $823 \mathrm{e} 9$.

27. Uzun I, Buyuk Y, Gurpinar K. Suicidal Hanging: Fatalities In Istanbul Retrospective Analysis of 761 Autopsy Cases. J For Leg Med 2007; 14(7): 406-409.

28. Suicidal hanging in Kuwait: Retrospective analysis of cases from 2010 to 2012, Journal of Forensic and Legal Medicine 20(8): 1118-1121.

29. Factors influencing the decision to use hanging as a method of suicide: qualitative study. Lucy Biddle, Jenny Donovan, Amanda Owen-Smith, John Potokar, Damien Longson, Keith Hawton, 
Nav Kapur, David Gunnell. The British Journal of Psychiatry Sep 2010; 197(4): 320-325.

30. Hawton $K$, Williams $K$. Influences of the media on suicide. BMJ 2002; 325: 1374-1375.

31. Gupta SC, Singh H. Psychiatric illness in Suicidal attempters. Ind J Psychiatry 1981; 23(1): 69-74.

32. Narang RL, Mishra BP, Nitesh M. 2000 Attempted suicide in Ludhiana. Ind J Psychiatry 2000; 42(1): 83-87.

33. Retrospective Study of Postmortem Cases of 'Hanging - A Method Of Suicide' Mohammed Ziyauddin G Saiyed, Kamesh A Modi NHL Journal of Medical Sciences/July 2013: 1.2(2).
34. Suicidal Hanging: A Prospective Study N. Vijayakumari J Indian Acad Forensic Med. October- December 2011, Vol. 33, No. 4.

35. Cantor, C.H., \& Baume, P.J.M. (1998). Access to methods of suicide: What impact? Australia and New Zealand Journal of Psychiatry, 32, 8-1.

36. Gunnell D, Bennewith O, Hawton K, Simkin S, Kapur N. The epidemiology and prevention of suicide by hanging: a systematic review. Int J Epidemiol. 2005, Apr; 34(2): 433-42. Review. PubMed PMID: 15659471. 